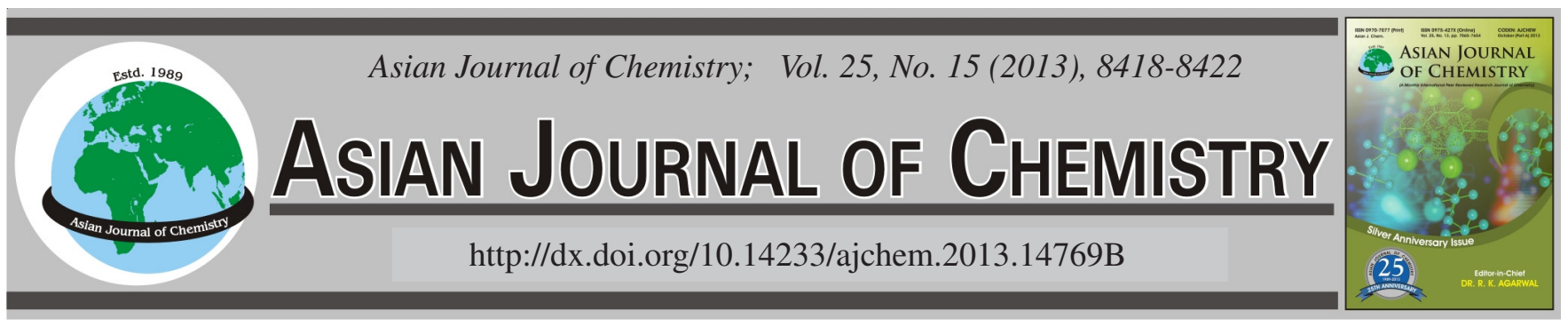

\title{
Synthesis, Crystal Structure and Fluorescence Spectrum of a \\ Europium Compound $\left[\mathrm{Eu}\left(\mathrm{NO}_{3}\right)_{3}\left(\mathrm{H}_{2} \mathrm{O}\right)_{4}\right] \cdot\left(\mathrm{C}_{10} \mathrm{H}_{9} \mathrm{~N}_{2}\right)_{2} \cdot\left(\mathrm{NO}_{3}\right)_{2}$
}

\author{
XIAO-Ju Chen ${ }^{1}$, WeI-Ji Hu ${ }^{2}$, Yi Qin ${ }^{2}$ and Guo-Liang ZhaO ${ }^{1,2, *}$
}

${ }^{1}$ College of Chemistry and Life Science, Zhejiang Normal University, Jinhua 321004, P.R. China

${ }^{2}$ Xingzhi College, Zhejiang Normal University, Jinhua 321004, P. R. China

*Corresponding author: Fax: +86 579 82282269; Tel: +86 579 82282061; E-mail: sky53@zjnu.cn

(Received: 3 November 2012;

Accepted: 23 August 2013)

AJC-13965

\begin{abstract}
A europium compound with the general molecular composition $\left[\mathrm{Eu}\left(\mathrm{NO}_{3}\right)_{3}\left(\mathrm{H}_{2} \mathrm{O}\right)_{4}\right] \cdot\left(\mathrm{C}_{10} \mathrm{H}_{9} \mathrm{~N}_{2}\right)_{2} \cdot\left(\mathrm{NO}_{3}\right)_{2}$ was synthesized from 4,4'-bipyridyl and $\mathrm{Eu}\left(\mathrm{NO}_{3}\right)_{3} \cdot 6 \mathrm{H}_{2} \mathrm{O}$ in ethanol and characterized by elemental analysis, molar conductance, IR, TG and X-ray crystallographically. The single-crystal X-ray diffraction studies demonstrated that compound is crystallize in triclinic system, space group $\mathrm{P}_{\mathrm{i}}$, with $\mathrm{a}=0.8112(3)$ $\mathrm{nm}, \mathrm{b}=1.2797(3) \mathrm{nm}, \mathrm{c}=1.5164(2) \mathrm{nm}, \alpha=95.158^{\circ}, \beta=101.732^{\circ}, \gamma=100.174^{\circ}, \mathrm{V}=1.504(2) \mathrm{nm}^{3}, \mathrm{Z}=2, \mathrm{M}_{\mathrm{r}}=848.46, \mathrm{~F}_{(000)}=848.0$, $\mathrm{D}_{\mathrm{c}}=1.873 \mathrm{~g} \mathrm{~cm}^{-3}, \mu\left(\mathrm{M}_{0} \mathrm{~K}_{\alpha}\right)=1.056 \mathrm{~mm}^{-1}$. It turned out that three nitrate anions coordinate to Eu(III) as bidentate and four water molecules coordinate to $\mathrm{Eu}(\mathrm{III})$, forming a ten-coordination distorted dicapped square antiprism geometry. In addition, the luminescent property and fluorescence quenching interaction with EB-DNA have been studied. CCDC: 871243.
\end{abstract}

Key Words: Europium compound, 4.4'-Bipyridyl, Crystal structure, Luminescent property, EB-DNA.

\section{INTRODUCTION}

Lanthanide complexes have grabbed some serious attention rapidly in function material field. Not only for the varieties of coordination model ${ }^{1,2}$, but also for their special chemical and physical characteristics arising from $4 f$ electrons, such as fluorescent ${ }^{3-5}$ and magnetism ${ }^{6,7}$. Taking advantage of the high affinity with oxygen, the high and variable coordination numbers, flexible coordination geometry of lanthanide ions, a number of lanthanide compounds with diverse dimensionality and topologies have been synthesized $^{4,5}$. Most of which have narrow emission bands, high fluorescence efficiencies and excellent fluorescence monochromaticity, so they can be applied in a lots of areas such as organic electroluminescent devices, light conversion materials, optical microcavity emitters, etc. ${ }^{8,9}$. Among them, the $\mathrm{Eu}^{3+}$ compounds is one of the most important luminescent materials, their strong red, long-lived and line-like emissions have made them of widespread interest for a series of applications from biological assays to display devices ${ }^{10,11}$. In this paper a new $\mathrm{Eu}^{3+}$ compound was prepared and the optical properties were investigated in detail. As an extension of our work in this field, the DNA-binding property of the compound were investigated by spectrophotometric method. The experimental results suggest that the compound bind to DNA in an intercalation mode.

\section{EXPERIMENTAL}

All reagents and solvents used were of commercially available quality and without purified before using. FTIR spectra were recorded on a Nicolet NEXUS 670 FTIR spectrophotometer using $\mathrm{KBr}$ discs in the range of $4000-400 \mathrm{~cm}^{-1}$. Elemental analysis was performed on C, H, N elemental analyzer, Elementar Vario EL III. A Mettler Toledo thermal analyzer TGA/SDTA $851^{\mathrm{e}}$ was used to carry out the thermoanalytical analysis with a heating rate of $10^{\circ} \mathrm{C} \mathrm{min}^{-1}$ from $30-800{ }^{\circ} \mathrm{C}$ in air atomsphere. Molar conductance was recorded on a DDS$11 \mathrm{~A}$ conductivity meter at $25^{\circ} \mathrm{C}$. Fluorescent spectrum were recorded at room temperature on an Edinburgh FL920 phosphorimeter.

Synthesis of the compound: 4,4'-Bipyridyl $(0.156 \mathrm{~g}, 1$ mmol) was dosolved in ethanol $(10 \mathrm{~mL})$, then $\mathrm{Eu}\left(\mathrm{NO}_{3}\right)_{3} \cdot 6 \mathrm{H}_{2} \mathrm{O}$ $(0.485 \mathrm{~g}, 1 \mathrm{mmol})$ dissolved in water $(10 \mathrm{~mL})$ was added to the above solution with stirring for $3 \mathrm{~h}$. After filtration, the filtrate was allowed to stand at room temperature and single crystals suitable for X-ray work were obtained after two weeks. Yield: $46 \%$ based on $\mathrm{Eu}\left(\mathrm{NO}_{3}\right)_{3} \cdot 6 \mathrm{H}_{2} \mathrm{O}$. Anal. calcd. (\%) for $\mathrm{C}_{20} \mathrm{H}_{26} \mathrm{~N}_{9} \mathrm{O}_{19} \mathrm{Eu}$ : C, 28.33; H, 3.09; N, 14.86; Eu, 17.91. Found (\%): C, 28.57; H, 3.21; N, 14.64; Eu, 17.73. IR (KBr, $\left.v_{\max }, \mathrm{cm}^{-1}\right)$ : 3443 (w), 3054(w), 1540 (s), 1523 (s), 1503 (s), 1414(s), 1384 (s), 1360(m), 1305(s), 1210(m), $1078(\mathrm{~s}), 1035(\mathrm{w}), 815(\mathrm{w})$, 715(w). 
Fluorescence quenching experiments: $2.0 \mathrm{~mL} \mathrm{EtBr}$ solution $\left(100 \mu \mathrm{g} \mathrm{mL}^{-1}\right)$ and $1 \mathrm{~mL}$ DNA solution $\left(200 \mu \mathrm{g} \mathrm{mL}^{-1}\right)$ were added to $10 \mathrm{~mL}$ colorimetric tube, the DNA-binding ability of the compound to EB-DNA was studied in $2 \mathrm{~mL}$ tris$\mathrm{HCl} / \mathrm{NaCl}$ buffer $(\mathrm{pH}=7.4)$. After standing for $2 \mathrm{~h}$, gradually with adding a certain amount of the compound solutions to the mixture at $4{ }^{\circ} \mathrm{C}$ and reacting for $12 \mathrm{~h}$. The excitement wavelength was aroused at $251 \mathrm{~nm}$ and each sample solution was scanned in the range $520-700 \mathrm{~nm}$.

X-Ray crystallography: A single crystal of the compound with dimentions of $0.354 \mathrm{~mm} \times 0.288 \mathrm{~mm} \times 0.202 \mathrm{~mm}$ was selected and mounted on a glass fiber and collected diffraction data on a Bruker Smart APEX II CCD diffractometer with graphite monochromated $\mathrm{M}_{0} \mathrm{~K}_{\alpha}$ radiation $(\lambda=0.071073 \mathrm{~nm})$ at 296(2) K. Structure was solved by direct methods using SHELXS- $97^{12}$ and refined on the $\mathrm{F}^{2}$ by full-matrix least-square method with SHELXL-97 ${ }^{13}$. All non-hydrogen atoms were refined anisotropically. Hydrogen atoms were placed in geometrically calculated positions and refined by using a riding mode. Experimental details for X-ray data collection are presented in Table-1 and the selected bond lengths and angles are listed in Table-2. CCDC No. 871243 of 1 contains the supplementary crystallographic data for this paper. These data can be obtained free of charge from the Cambridge Crystallographic Data Centre.

\begin{tabular}{|c|c|c|c|}
\hline \multicolumn{4}{|c|}{$\begin{array}{c}\text { TABLE-1 } \\
\text { CRYSTALLOGRAPHIC DATA FOR THE COMPLEX }\end{array}$} \\
\hline Empirical formula & $\mathrm{C}_{20} \mathrm{H}_{26} \mathrm{~N}_{9} \mathrm{O}_{19} \mathrm{Eu}$ & Calculated density $\left(\mathrm{Mg} / \mathrm{m}^{3}\right)$ & 1.873 \\
\hline Formula weight & 848.46 & Absorption coefficient $\left(\mathrm{mm}^{-1}\right)$ & 2.186 \\
\hline Temperature $(\mathrm{K})$ & $296(2)$ & $\mathrm{F}_{(000)}$ & 848.0 \\
\hline Wavelength (nm) & 0.071073 & Crystal size (mm) & $0.354 \times 0.288 \times 0.202$ \\
\hline Crystal system & Triclinic & $\theta$ range for data collection $\left({ }^{\circ}\right)$ & 1.63 to 27.53 \\
\hline Space group & $\mathrm{P}_{1}$ & Limiting indices & $-10 \Leftarrow \mathrm{h} \Leftarrow 10,-16 \Leftarrow \mathrm{k} \Leftarrow 16,-19 \Leftarrow 1 \Leftarrow 19$ \\
\hline $\mathrm{a}(\mathrm{nm})$ & $0.8112(3)$ & Reflections collected/unique & $23896 / 6866\left[\mathrm{R}_{(\mathrm{int})}=0.0225\right]$ \\
\hline $\mathrm{b}(\mathrm{nm})$ & $1.2797(3)$ & Refinement method & Full-matrix least-squares on $\mathrm{F}^{2}$ \\
\hline $\mathrm{c}(\mathrm{nm})$ & $1.5164(2)$ & Data/restraints/parameters & $6866 / 0 / 446$ \\
\hline$\alpha\left({ }^{\circ}\right)$ & $95.158(1)$ & Goodness-of-fit (on $\mathrm{F}^{2}$ ) & 0.997 \\
\hline$\beta\left({ }^{\circ}\right)$ & $101.732(1)$ & Final $R$ indices $[I>2 \sigma(I)]$ & $\mathrm{R}_{1}=0.0189, \mathrm{wR}_{2}=0.0485$ \\
\hline$\gamma\left(\left(^{\circ}\right)\right.$ & $100.174(1)$ & $\mathrm{R}$ indices (all data) & $\mathrm{R}_{1}=0.0211, \mathrm{wR}_{2}=0.0498$ \\
\hline Volume $\left(\mathrm{nm}^{3}\right)$ & $1.50417(2)$ & $\Delta \rho \max , \Delta \rho \min \left(\mathrm{e} \mathrm{nm}^{-3}\right)$ & 540 and -494 \\
\hline Z & 2 & - & - \\
\hline
\end{tabular}

\begin{tabular}{|c|c|c|c|c|c|}
\hline \multicolumn{6}{|c|}{$\begin{array}{c}\text { TABLE } 2 \\
\text { SELECTED BOND LENGTHS }(\mathrm{nm}) \text { AND ANGLES }\left({ }^{\circ}\right)\end{array}$} \\
\hline Bond & Length & Bond & Length & Bond & Length \\
\hline $\mathrm{Eu}(1)-\mathrm{O}(1 \mathrm{~W})$ & $0.24058(15)$ & $\mathrm{Eu}(1)-\mathrm{O}(5)$ & $0.24786(14)$ & $\mathrm{Eu}(1)-\mathrm{O}(13)$ & $0.25589(15)$ \\
\hline $\mathrm{Eu}(1)-\mathrm{O}(2 \mathrm{~W})$ & $0.24070(14)$ & $\mathrm{Eu}(1)-\mathrm{O}(12)$ & $0.24967(14)$ & $\mathrm{Eu}(1)-\mathrm{O}(8)$ & $0.25900(15)$ \\
\hline $\mathrm{Eu}(1)-\mathrm{O}(3 \mathrm{~W})$ & $0.24129(14)$ & $\mathrm{Eu}(1)-\mathrm{O}(10)$ & $0.25232(15)$ & $\mathrm{Eu}(1)-\mathrm{O}(6)$ & $0.28067(16)$ \\
\hline $\mathrm{Eu}(1)-\mathrm{O}(4 \mathrm{~W})$ & $0.24607(14)$ & - & - & - & - \\
\hline Angle & $\left({ }^{\circ}\right)$ & Angle & $\left({ }^{\circ}\right)$ & Angle & $\left({ }^{\circ}\right)$ \\
\hline $\mathrm{O}(1 \mathrm{~W})-\mathrm{Eu}(1)-\mathrm{O}(2 \mathrm{~W})$ & $78.47(6)$ & $\mathrm{O}(13)-\mathrm{Eu}(1)-\mathrm{O}(6)$ & $104.52(5)$ & $\mathrm{O}(3 \mathrm{~W})-\mathrm{Eu}(1)-\mathrm{O}(8)$ & $70.66(5)$ \\
\hline $\mathrm{O}(1 \mathrm{~W})-\mathrm{Eu}(1)-\mathrm{O}(3 \mathrm{~W})$ & $74.28(5)$ & $\mathrm{O}(8)-\mathrm{Eu}(1)-\mathrm{O}(6)$ & $104.42(5)$ & $\mathrm{O}(4 \mathrm{~W})-\mathrm{Eu}(1)-\mathrm{O}(8)$ & $67.16(5)$ \\
\hline $\mathrm{O}(2 \mathrm{~W})-\mathrm{Eu}(1)-\mathrm{O}(3 \mathrm{~W})$ & $71.79(5)$ & $\mathrm{O}(1 \mathrm{~W})-\mathrm{Eu}(1)-\mathrm{N}(6)$ & $73.84(5)$ & $\mathrm{O}(5)-\mathrm{Eu}(1)-\mathrm{O}(8)$ & $66.50(5)$ \\
\hline $\mathrm{O}(1 \mathrm{~W})-\mathrm{Eu}(1)-\mathrm{O}(4 \mathrm{~W})$ & $138.57(5)$ & $\mathrm{O}(2 \mathrm{~W})-\mathrm{Eu}(1)-\mathrm{N}(6)$ & $96.79(5)$ & $\mathrm{O}(12)-\mathrm{Eu}(1)-\mathrm{O}(8)$ & $149.73(5)$ \\
\hline $\mathrm{O}(2 \mathrm{~W})-\mathrm{Eu}(1)-\mathrm{O}(4 \mathrm{~W})$ & $131.88(5)$ & $\mathrm{O}(3 \mathrm{~W})-\mathrm{Eu}(1)-\mathrm{N}(6)$ & $147.70(5)$ & $\mathrm{O}(5)-\mathrm{Eu}(1)-\mathrm{N}(7)$ & $91.14(5)$ \\
\hline $\mathrm{O}(3 \mathrm{~W})-\mathrm{Eu}(1)-\mathrm{O}(4 \mathrm{~W})$ & $135.34(5)$ & $\mathrm{O}(4 \mathrm{~W})-\mathrm{Eu}(1)-\mathrm{N}(6)$ & $74.87(5)$ & $\mathrm{O}(12)-\mathrm{Eu}(1)-\mathrm{N}(7)$ & $133.41(5)$ \\
\hline $\mathrm{O}(1 \mathrm{~W})-\mathrm{Eu}(1)-\mathrm{O}(5)$ & $146.10(5)$ & $\mathrm{O}(5)-\mathrm{Eu}(1)-\mathrm{N}(6)$ & $133.06(4)$ & $\mathrm{O}(10)-\mathrm{Eu}(1)-\mathrm{N}(7)$ & $24.85(5)$ \\
\hline $\mathrm{O}(2 \mathrm{~W})-\mathrm{Eu}(1)-\mathrm{O}(5)$ & $78.00(5)$ & $\mathrm{O}(12)-\mathrm{Eu}(1)-\mathrm{N}(6)$ & $25.21(5)$ & $\mathrm{O}(13)-\mathrm{Eu}(1)-\mathrm{N}(7)$ & $84.61(5)$ \\
\hline $\mathrm{O}(3 \mathrm{~W})-\mathrm{Eu}(1)-\mathrm{O}(5)$ & $75.38(5)$ & $\mathrm{O}(10)-\mathrm{Eu}(1)-\mathrm{N}(6)$ & $90.95(5)$ & $\mathrm{O}(8)-\mathrm{Eu}(1)-\mathrm{N}(7)$ & $25.19(5)$ \\
\hline $\mathrm{O}(4 \mathrm{~W})-\mathrm{Eu}(1)-\mathrm{O}(5)$ & $75.01(5)$ & $\mathrm{O}(13)-\mathrm{Eu}(1)-\mathrm{N}(6)$ & $24.84(5)$ & $\mathrm{O}(6)-\mathrm{Eu}(1)-\mathrm{N}(7)$ & $122.11(5)$ \\
\hline $\mathrm{O}(1 \mathrm{~W})-\mathrm{Eu}(1)-\mathrm{O}(12)$ & $78.83(5)$ & $\mathrm{O}(8)-\mathrm{Eu}(1)-\mathrm{N}(6)$ & $129.51(5)$ & $\mathrm{N}(6)-\mathrm{Eu}(1)-\mathrm{N}(7)$ & $108.90(5)$ \\
\hline $\mathrm{O}(2 \mathrm{~W})-\mathrm{Eu}(1)-\mathrm{O}(12)$ & $73.48(5)$ & $\mathrm{O}(6)-\mathrm{Eu}(1)-\mathrm{N}(6)$ & $86.91(5)$ & $\mathrm{O}(1 \mathrm{~W})-\mathrm{Eu}(1)-\mathrm{H}(1 \mathrm{WA})$ & 13.9 \\
\hline $\mathrm{O}(3 \mathrm{~W})-\mathrm{Eu}(1)-\mathrm{O}(12)$ & $139.42(5)$ & $\mathrm{O}(1 \mathrm{~W})-\mathrm{Eu}(1)-\mathrm{N}(7)$ & $98.67(5)$ & $\mathrm{O}(2 \mathrm{~W})-\mathrm{Eu}(1)-\mathrm{H}(1 \mathrm{WA})$ & 72.6 \\
\hline $\mathrm{O}(4 \mathrm{~W})-\mathrm{Eu}(1)-\mathrm{O}(12)$ & $84.25(5)$ & $\mathrm{O}(3 \mathrm{~W})-\mathrm{Eu}(1)-\mathrm{O}(10)$ & $86.95(5)$ & $\mathrm{O}(3 \mathrm{~W})-\mathrm{Eu}(1)-\mathrm{H}(1 \mathrm{WA})$ & 60.6 \\
\hline $\mathrm{O}(5)-\mathrm{Eu}(1)-\mathrm{O}(12)$ & $116.81(5)$ & $\mathrm{O}(4 \mathrm{~W})-\mathrm{Eu}(1)-\mathrm{O}(10)$ & $76.95(5)$ & $\mathrm{O}(4 \mathrm{~W})-\mathrm{Eu}(1)-\mathrm{H}(1 \mathrm{WA})$ & 150.5 \\
\hline $\mathrm{O}(1 \mathrm{~W})-\mathrm{Eu}(1)-\mathrm{O}(10)$ & $77.12(6)$ & $\mathrm{O}(5)-\mathrm{Eu}(1)-\mathrm{O}(10)$ & $115.96(5)$ & $\mathrm{O}(5)-\mathrm{Eu}(1)-\mathrm{H}(1 \mathrm{WA})$ & 132.6 \\
\hline $\mathrm{O}(2 \mathrm{~W})-\mathrm{Eu}(1)-\mathrm{O}(10)$ & $151.17(6)$ & $\mathrm{O}(12)-\mathrm{Eu}(1)-\mathrm{O}(10)$ & $116.03(5)$ & $\mathrm{O}(12)-\mathrm{Eu}(1)-\mathrm{H}(1 \mathrm{WA})$ & 89.4 \\
\hline $\mathrm{O}(10)-\mathrm{Eu}(1)-\mathrm{O}(8)$ & $49.63(5)$ & $\mathrm{O}(1 \mathrm{~W})-\mathrm{Eu}(1)-\mathrm{O}(13)$ & $71.68(5)$ & $\mathrm{O}(10)-\mathrm{Eu}(1)-\mathrm{H}(1 \mathrm{WA})$ & 80.1 \\
\hline $\mathrm{O}(13)-\mathrm{Eu}(1)-\mathrm{O}(8)$ & $107.16(5)$ & $\mathrm{O}(2 \mathrm{~W})-\mathrm{Eu}(1)-\mathrm{O}(13)$ & $119.43(5)$ & $\mathrm{O}(13)-\mathrm{Eu}(1)-\mathrm{H}(1 \mathrm{WA})$ & 85.4 \\
\hline $\mathrm{O}(1 \mathrm{~W})-\mathrm{Eu}(1)-\mathrm{O}(6)$ & $138.85(5)$ & $\mathrm{O}(3 \mathrm{~W})-\mathrm{Eu}(1)-\mathrm{O}(13)$ & $140.33(5)$ & $\mathrm{O}(8)-\mathrm{Eu}(1)-\mathrm{H}(1 \mathrm{WA})$ & 110.4 \\
\hline $\mathrm{O}(2 \mathrm{~W})-\mathrm{Eu}(1)-\mathrm{O}(6)$ & $67.93(5)$ & $\mathrm{O}(4 \mathrm{~W})-\mathrm{Eu}(1)-\mathrm{O}(13)$ & $68.48(5)$ & $\mathrm{O}(6)-\mathrm{Eu}(1)-\mathrm{H}(1 \mathrm{WA})$ & 139.0 \\
\hline $\mathrm{O}(3 \mathrm{~W})-\mathrm{Eu}(1)-\mathrm{O}(6)$ & $114.47(5)$ & $\mathrm{O}(5)-\mathrm{Eu}(1)-\mathrm{O}(13)$ & $141.90(5)$ & $\mathrm{N}(6)-\mathrm{Eu}(1)-\mathrm{H}(1 \mathrm{WA})$ & 87.2 \\
\hline $\mathrm{O}(4 \mathrm{~W})-\mathrm{Eu}(1)-\mathrm{O}(6)$ & $64.39(5)$ & $\mathrm{O}(12)-\mathrm{Eu}(1)-\mathrm{O}(13)$ & $50.04(5)$ & $\mathrm{N}(7)-\mathrm{Eu}(1)-\mathrm{H}(1 \mathrm{WA})$ & 98.1 \\
\hline $\mathrm{O}(5)-\mathrm{Eu}(1)-\mathrm{O}(6)$ & $47.52(4)$ & $\mathrm{O}(10)-\mathrm{Eu}(1)-\mathrm{O}(13)$ & $66.21(5)$ & $\mathrm{O}(2 \mathrm{~W})-\mathrm{Eu}(1)-\mathrm{N}(7)$ & $152.38(5)$ \\
\hline $\mathrm{O}(12)-\mathrm{Eu}(1)-\mathrm{O}(6)$ & $69.56(5)$ & $\mathrm{O}(1 \mathrm{~W})-\mathrm{Eu}(1)-\mathrm{O}(8)$ & $115.96(5)$ & $\mathrm{O}(3 \mathrm{~W})-\mathrm{Eu}(1)-\mathrm{N}(7)$ & $80.95(5)$ \\
\hline $\mathrm{O}(10)-\mathrm{Eu}(1)-\mathrm{O}(6)$ & $140.47(5)$ & $\mathrm{O}(2 \mathrm{~W})-\mathrm{Eu}(1)-\mathrm{O}(8)$ & $133.31(5)$ & $\mathrm{O}(4 \mathrm{~W})-\mathrm{Eu}(1)-\mathrm{N}(7)$ & $67.03(5)$ \\
\hline
\end{tabular}




\section{RESULTS AND DISCUSSION}

IR spectrum and molar conductance: For the IR spectrum of compound $\mathbf{1}$, there is a broad weak peak observed at near $3443 \mathrm{~cm}^{-1}$, which corresponds to the stretching vibrations of $\mathrm{O}-\mathrm{H}$ of coordinated water molecules. The presence of broad bond at $3054 \mathrm{~cm}^{-1}$ indicating the hydrogen bonds between the $\mathrm{N}-\mathrm{H}$ bonds and other atoms. The features at 1503, 1305, 1035, 815 and $715 \mathrm{~cm}^{-1}$ may be assigned to the bidentate coordinated nitrate radical. While the strong peak at about $1384 \mathrm{~cm}^{-1}$ is associated with the free nitrate radical. The free ligand 4,4'bipyH in the compound shows characteristic absorption bands at $1523,1414,1210$ and $1078 \mathrm{~cm}^{-1}$, which is well consistent with X-ray diffraction structural analysis.

The molar conductance of compound 1 was conducted at $25^{\circ} \mathrm{C}$, the observed molar conductance value in $1.0 \times 10^{-3} \mathrm{~mol}$ $\mathrm{L}^{-1}$ aqueous DMF solution is $101.8 \mathrm{~S} \mathrm{~cm}^{2} \mathrm{~mol}^{-1}$, which indicating that the compound $\mathbf{1}$ is electrolyte, suggesting two nitrate anions show negative bivalent in outer sphere, while two protonated 4,4'-bipyridy balancing the charge in outer sphere. This is consistent with the single-crystal X-ray analyses.

Structural description: The crystal structure of the compound is shown in Fig. 1 the asymmetric unit of the compound $\left[\mathrm{Eu}\left(\mathrm{NO}_{3}\right)_{3}\left(\mathrm{H}_{2} \mathrm{O}\right)_{4}\right] \cdot(4,4 \text { '-bipyH })_{2} \cdot\left(\mathrm{NO}_{3}\right)_{2}$ consists of one $\mathrm{Eu}(\mathrm{III})$, five $\mathrm{NO}_{3}{ }^{-}$, two 4,4'-bipyH and four water. $\mathrm{Eu}$ (III) atom is coordinated with three $\mathrm{NO}_{3}{ }^{-}$and four water. The $\mathrm{NO}_{3}{ }^{-}$ are bidentate so that the $\mathrm{Eu}$ atom is ten-coordinate (Fig. 2). Average bond lengths are: Eu-O (nitrate), $0.25757 \mathrm{~nm}$; $\mathrm{Eu}-\mathrm{OH}_{2}, 0.24216 \mathrm{~nm}$, which are similar to the reported complexes $\left[\mathrm{Yb}\left(\mathrm{NO}_{3}\right)_{3}\left(\mathrm{H}_{2} \mathrm{O}\right)_{4}\right] \cdot 2(4$-bipyH $)\left(\mathrm{NO}_{3}\right)(\mathrm{III})$ and $\left[\mathrm{Nd}\left(\mathrm{NO}_{3}\right)_{3}\left(\mathrm{H}_{2} \mathrm{O}\right)_{4}\right] \cdot 2(4-$ bipyH $)\left(\mathrm{NO}_{3}\right)(\mathrm{III})^{14}$. The coordination geometry can be described as follows. Compound present an distorted dicapped square antiprism geometry. Atoms O1W, O2W, O6 and O13 define a quadrangle and the other quadrangle of atoms $\mathrm{O} 3 \mathrm{~W}, \mathrm{O} 4 \mathrm{~W}, \mathrm{O} 5, \mathrm{O} 10$ are below the plane. Two cap atoms $\mathrm{O} 12$ and O8, respectively occupy the top and bottom of the square antiprism. The shorter $\mathrm{H}_{2} \mathrm{O}-\mathrm{N}$ (bipy) distances and the near-collinearity of the $\mathrm{H}_{2} \mathrm{O}-\mathrm{N}$ vectors with the 4,4'-bipyridyl N-N axes strongly imply the presence of hydrogen bonds (Table-3). The resulting three-dimensional net is reinforced by $\mathrm{NO}_{3}-\mathrm{H}_{2} \mathrm{O}$ bonds parallel to a axe. which is similar to the Ho compound ${ }^{15}$. The other two independent $\mathrm{NO}_{3}{ }^{-}$ lies on a general position and two lie on crystal inversion centres, while the independent protonated 4,4'-bipyridyl molecules are on general positions.
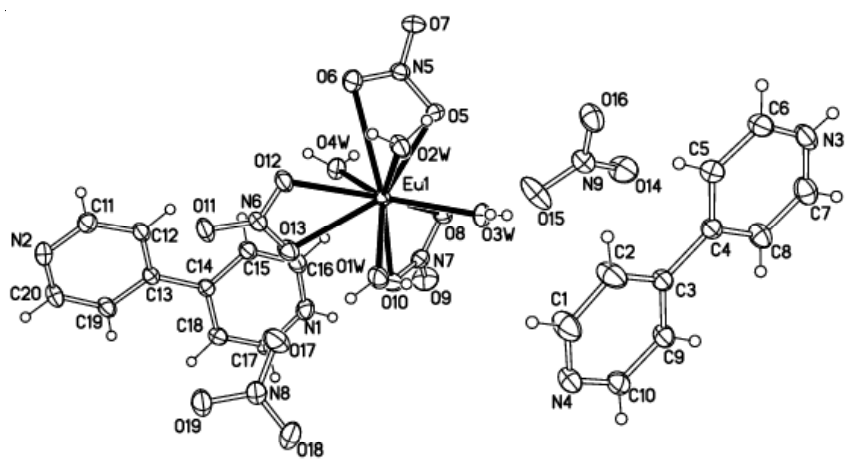

Fig. 1. Molecular structure of the title compound with thermal ellipsoids shown at the $30 \%$ level

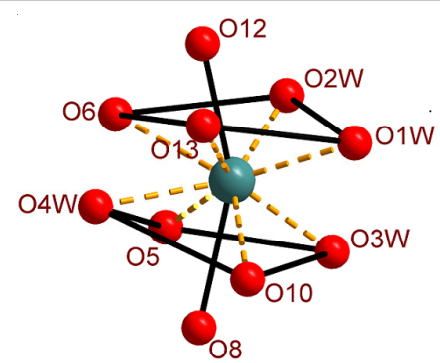

Fig. 2. Coordinate of the title compound

TABLE-3

HYDROGEN BOND GEOMETRY FOR TITLE COMPLEX $\left(\mathrm{nm},{ }^{\circ}\right)$

\begin{tabular}{lcccc}
\hline \multicolumn{1}{c}{ D-H $\cdots A$} & D-H & H $\cdots A$ & D $\cdots A$ & D-H $\cdots A$ \\
\hline $\mathrm{O}(1 \mathrm{~W})-\mathrm{H}(1 \mathrm{WB}) \ldots \mathrm{O}(17)$ & 0.078 & 0.198 & $0.2746(2)$ & 166.1 \\
$\mathrm{O}(1 \mathrm{~W})-\mathrm{H}(1 \mathrm{WA}) \ldots \mathrm{O}(7)^{\mathrm{i}}$ & 0.074 & 0.219 & $0.2914(2)$ & 166.0 \\
$\mathrm{O}(2 \mathrm{~W})-\mathrm{H}(2 \mathrm{WB}) \ldots \mathrm{N}(4)^{\mathrm{ii}}$ & 0.083 & 0.196 & $0.2786(2)$ & 173.1 \\
$\mathrm{O}(2 \mathrm{~W})-\mathrm{H}(2 \mathrm{WA}) \ldots \mathrm{O}(16)^{\mathrm{iii}}$ & 0.083 & 0.201 & $0.2839(2)$ & 177.3 \\
$\mathrm{O}(3 \mathrm{~W})-\mathrm{H}(3 \mathrm{WB}) \ldots \mathrm{N}(2)^{\mathrm{iv}}$ & 0.079 & 0.199 & $0.2765(2)$ & 169.0 \\
$\mathrm{O}(3 \mathrm{~W})-\mathrm{H}(3 \mathrm{WA}) \ldots \mathrm{O}(15)$ & 0.075 & 0.220 & $0.2933(2)$ & 163.9 \\
$\mathrm{O}(4 \mathrm{~W})-\mathrm{H}(4 \mathrm{WB}) \ldots \mathrm{O}(18)^{\mathrm{ii}}$ & 0.079 & 0.190 & $0.2678(2)$ & 167.0 \\
$\mathrm{O}(4 \mathrm{~W})-\mathrm{H}(4 \mathrm{WA}) \ldots \mathrm{O}(9)^{\mathrm{v}}$ & 0.077 & 0.217 & $0.2892(2)$ & 157.0 \\
$\mathrm{~N}(3)-\mathrm{H}(80 \mathrm{~A}) \ldots \mathrm{O}(16)^{\mathrm{vi}}$ & 0.075 & 0.209 & $0.2811(3)$ & 160.6 \\
$\mathrm{~N}(1)-\mathrm{H}(81 \mathrm{~A}) \ldots \mathrm{O}(7)^{\mathrm{v}}$ & 0.079 & 0.217 & $0.2957(3)$ & 173.3 \\
\hline
\end{tabular}

Symmetry codes: ${ }^{\mathrm{i}} \mathrm{x}-1, \mathrm{y}, \mathrm{z} ;{ }^{\prime} \mathrm{x}+1, \mathrm{y}, \mathrm{z} ;{ }^{\prime}-\mathrm{x}+1,-\mathrm{y}+1,-\mathrm{z} ;{ }^{\mathrm{P}} \mathrm{x}, \mathrm{y}+1, \mathrm{z} ;{ }^{\prime}-\mathrm{x}+2,-$ $\mathrm{y}+1,-\mathrm{z}+1 ;{ }^{\prime}-\mathrm{x}+1,-\mathrm{y}+2,-\mathrm{z}$.

In addition, there are infinite parallel aromatic rings from the 4,4'-bipyridyl, the 4,4'-bipyridyl cycles between two adjacent molecules are parallel with the centroid distance of $0.36681 \mathrm{~nm}$. Hence the hydrogen bonds andp-pstacking interactions strengthen the stability of coordination compound (Fig. 3).

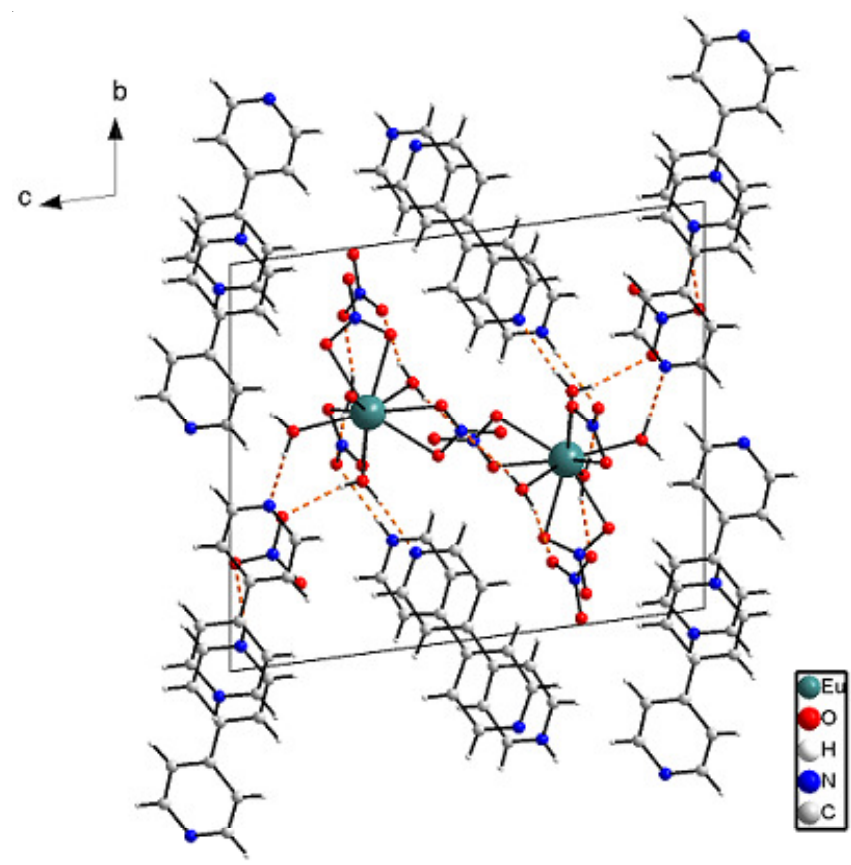

Fig. 3. Packing plot of the title compound

Thermogravimetric analysis: The thermogravimetric analyses of the compound was conducted under air atmosphere when they were heated to $800^{\circ} \mathrm{C}$ with a $10^{\circ} \mathrm{C} \mathrm{min}^{-1}$ temperature ramp (Fig. 4). The TG diagram reveals two distinct weight 


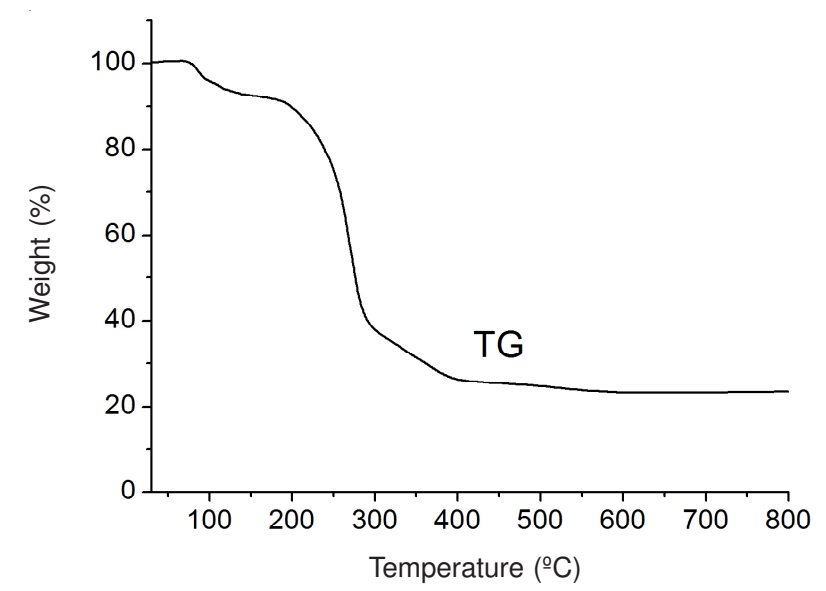

Fig. 4. TG of the title compound

regions. The first weight loss of $8.84 \%$ (calcd. $8.49 \%$ ) corresponds to the release of four water molecule from $80-155^{\circ} \mathrm{C}$. The further decomposition occurred in the range of 200-420 ${ }^{\circ} \mathrm{C}$ with the weight loss of $70.23 \%$ (calcd. $70.82 \%$ ), which is attributed to the elimination of five $\mathrm{NO}_{3}{ }^{-}$and two protonized 4,4'-bipyridyl. The residue weights $20.93 \%$ corresponds to values calculated for $\mathrm{Eu}_{2} \mathrm{O}_{3} 20.74 \%$. This result is in good accordance with the composition of the compound.

Fluorescent property: As shown in Fig. 5(a), intense red luminescence and exhibits characteristic peaks at 532, 590, 614, 647 and $695 \mathrm{~nm}$ can be observed, which are assainged to the $4 f \rightarrow 4 f$ transitions of the ${ }^{5} \mathrm{D}_{0}$ to ${ }^{7} \mathrm{~F}_{\mathrm{J}}(\mathrm{J}=0,1,2,3$ and 4$)$ levels of $\mathrm{Eu}(\mathrm{III})$. It is well-known that for the $\mathrm{Eu}(\mathrm{III})$ ion, the ${ }^{5} \mathrm{D}_{0} \rightarrow{ }^{7} \mathrm{~F}_{2}$ transition is hypersensitive to its site symmetry and of electric-dipole (ED) nature, which is only permitted on the condition when the Eu(III) ion occupies a site without an inversion center according to Judd-Ofelt theory ${ }^{16}$. By contrast, the ${ }^{5} \mathrm{D}_{0} \rightarrow{ }^{7} \mathrm{~F}_{1}$ transition is insensitive to the site symmetry and of magnetic-dipole (MD) nature. The intensity ratio of the ${ }^{5} \mathrm{D}_{0} \rightarrow{ }^{7} \mathrm{~F}_{2}$ transition to ${ }^{5} \mathrm{D}_{0} \rightarrow{ }^{7} \mathrm{~F}_{1}$ transition reflects the information of the structures, such as ligand environments and site symmetry of $\mathrm{Eu}(\mathrm{III})$ ion. The intensity of the ${ }^{5} \mathrm{D}_{0} \rightarrow{ }^{7} \mathrm{~F}_{2}$ transition is much stronger than that of ${ }^{5} \mathrm{D}_{0} \rightarrow{ }^{7} \mathrm{~F}_{1}$ transition. These experimental facts suggest that the Eu(III) ion in compound $\mathbf{1}$ are not located at the symcenter, which is agree well with single-crystal X-ray analyses.

By comparing with the luminescence behaviour of pure free europium nitrate [Fig. 5(b)], it can be seen that the excitation is totally different, the feature excitation of the pure europium nitrate at $398 \mathrm{~nm}$, while the title compound with the excitation at $329 \mathrm{~nm}$ identical to the excitation of the 4,4'bipyridyl [Fig. 5(c)]. It is indicated that the emission for the title compound was enhanced may be due to 4,4'-bipyridyl can transfer the energy to the central metal efficiently and can sensitize the central metal.

Fluorescence quenching studies: Fig. 6 shows that the emission spectra of EB bounded to DNA with compound. Upon addition of the tested compound, the emission intensity at $598 \mathrm{~nm}$ of EB-DNA system decreased in different degrees, indicating that the compound competes with EB to bind with DNA. The fluorescence quenching constant (Ksq) of title compound is 1.82 , the quenching plots illustrate that the quenching of EB-bound EB-DNA system by the title compound agree

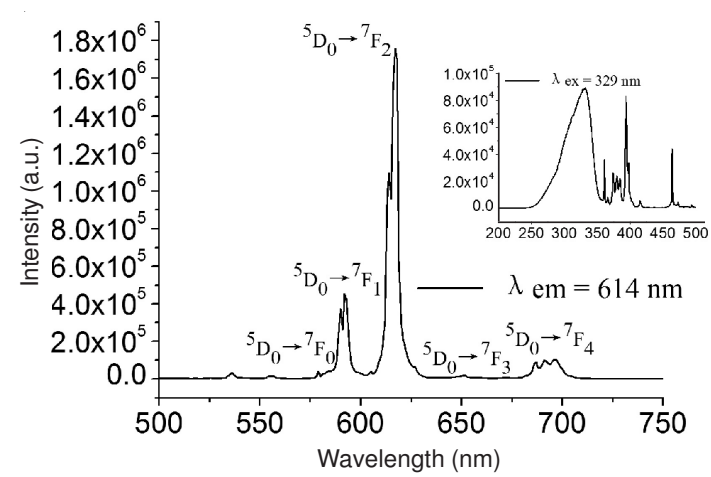

(a)

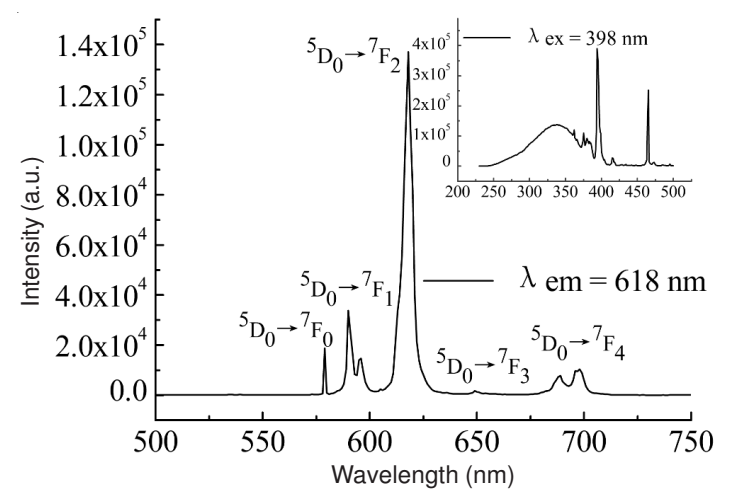

(b)

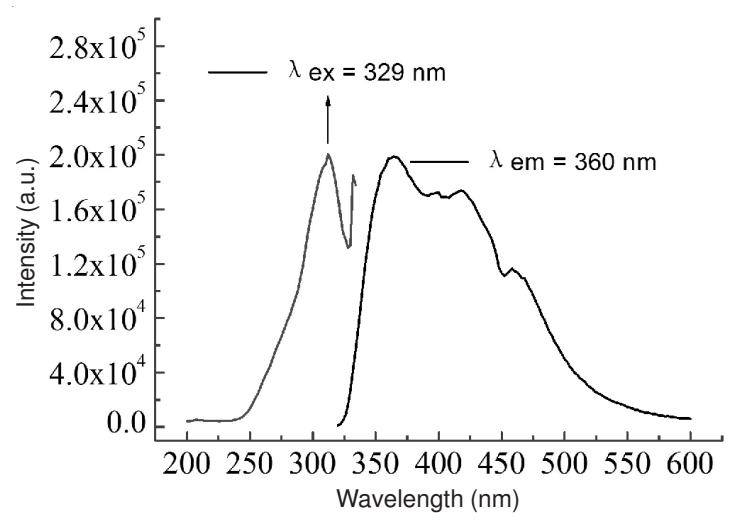

(c)

Fig. 5. Excitation and emission spectra in the solid state at room temperature: (a) the title compound (b) the pure europium nitrate (c) the 4,4'-bipyridyl

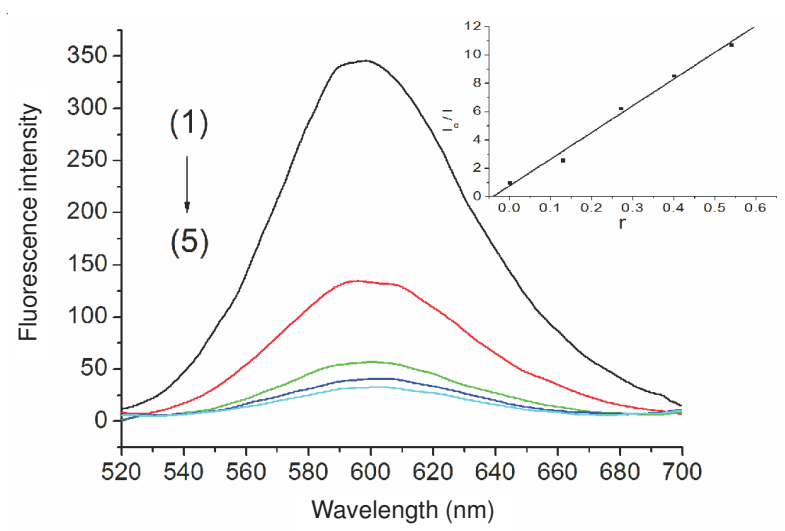

Fig. 6. Effects of the compound on the fluorescence spectra of EB-DNA $\operatorname{system}\left(r_{1}=0 ; r_{2}=1.30 ; r_{3}=2.70 ; r_{4}=4.00 ; r_{5}=5.40\right)$ 
well with the Stern-Volmer equation ${ }^{17}: \mathrm{I}_{0} / \mathrm{I}=1+$ Ksqr. It indicating that the compound could partially insert into the DNA double helix, because of the single cap four prism structures and the bipyridyl rings. These factors facilitate the compound to insert to the base of DNA molecule to compete with the combination of EB-DNA sites.

\section{REFERENCES}

1. G. Peng, Y.C. Qiu, Z.H. Liu, B. Liu and H. Deng, Cryst. Growth Des., 10, 114 (2010)

2. N.L. Rosi, J. Kim, M. Eddaoudi, B. Chen, M. O'Keeffe and O.M. Yaghi, J. Am. Chem. Soc., 127, 1504 (2005).

3. B.D. Chandler, D.T. Cram and G.K.H. Shimizu, J. Am. Chem. Soc., 128, 10403 (2006).

4. Y. Cui, H. Xu, Y. Yue, Z. Guo, J. Yu, Z. Chen, J. Gao, Y. Yang, G. Qian and B. Chen, J. Am. Chem. Soc., 134, 3979 (2012).

5. R. Kumar, V.B. Taxak, Dayawati and S.P. Khatkar, Asian J. Chem., 26 , (2014) (In press)
6. G.J.C. Buunzli and C. Piguet, Chem. Rev., 102, 1897 (2002).

7. D. Ananias, S. Ferdov, F.A. Almeida Paz, R.A. Sá Ferreira, A. Ferreira, C.F.G.C. Geraldes, L.D. Carlos, Z. Lin and J. Rocha, Chem. Mater., 20, 205 (2008).

8. D. Beljonne, J. Cornil, H. Sirringhaus, P.J. Brown, M. Shkunov, R.H. Friend and J.-L. Brédas, Adv. Funct. Mater., 11, 229 (2001).

9. F. Luo, Y.X. Che and J.M. Zheng, Cryst. Growth Des., 8, 2006 (2008).

10. E.G. Moore, J. Xu, C.J. Jocher, E.J. Werner and K.N. Raymond, J. Am. Chem. Soc., 128, 10648 (2006).

11. R.V. Deun, P. Nockemann, P. Fias, K.V. Hecke, L.V. Meervelt and K. Binnemans, Chem. Commun., 590 (2005).

12. G.M. Sheldrick, SHELXS-97, Program for the Solution of Crystal Structures. University of Götingen, Germany (1997).

13. G.M. Sheldrick, SHELXL-97, Program for the Refinement of Crystal Structures. University of Götingen, Germany (1997).

14. K. Al-Rasoul and T.J.R. Weakley, Inorg. Chim. Acta, 60, 191 (1982)

15. K. Kuriki and Y. Kolike, Chem. Rev., 102, 2347 (2002).

16. H.B. Zhang, N. Li, C.B. Tian, T.F. Liu, F.L. Du, P. Lin, Z.H. Li and S.W. Du, Cryst. Growth Des., 12, 670 (2012)

17. J.R. Lakowicz and G. Weber, Biochemistry, 42, 4161 (1973). 